\title{
CORYNEBACTERIUM RENALE AS A CAUSE OF REACTIONS TO THE COMPLEMENT FIXATION TEST FOR JOHNE'S DISEASE
}

\author{
By \\ N. J. L. GiLmour \\ Moredun Research Institute, Gilmerton, Edinburgh \\ and \\ J. GoudSWAard \\ Instituut voor Vet. Bacteriologie der Rijksuniversiteit, Utrecht, Netherlands
}

\section{INTRODUCTION}

Apparently non-specific reactions to the complement fixation (C.F.) test for Johne's disease have been reported when the test has been applied to clinically healthy cattle (Rankin, 1961). Sensitisation with other mycobacteria has been postulated as a cause of these non-specific reactions, but there have been no reports of studies to elucidate the position.

In the Friesland Provincial Veterinary Health Service laboratories (Reinders, 1963) and at the Institute of Veterinary Bacteriology, Utrecht (Goudswaard, 1971a) an impression was gained that cattle with symptoms of pyelonephritis gave positive reactions to the C.F. test for Johne's disease. Preliminary work at Utrecht tended to confirm this impression. Autopsies on a few of these cattle were carried out. There was no evidence of $M$. johnei infection, but Corynebacterium renale was isolated from urines, bladders or the pelvises of the kidneys. The fluorescent antibody (F.A.) test has been found to be specific in some experimental mycobacterial infections in rabbits (Gilmour, 1971).

We report here the use of the F.A. and C.F. tests in rabbits experimentally infected with $M$. johnei and $C$. renale, and in naturally occurring cases of pyelonephritis due to $C$. renale and in Johne's disease in cattle.

\section{MATERIALS AND METHODS}

Experimental animals. Young adult New Zealand White rabbits of an average weight $1.0 \mathrm{~kg}$.were used.

Inocula. Rabbits were inoculated at weekly intervals with $1 \mathrm{ml}$. Brown's tube 2 of $C$. renale. This strain, isolated from the urine of a cow with clinical signs of pyelonephritis, had all the biochemical characters of $C$. renale as described by Breed, Murray and Smith (1957). The first dose was given intravenously and the 2 subsequent doses subcutaneously. The same doses and schedule had been used in the $M$. johnei inoculated group of rabbits which formed part of a previous experiment. All essential conditions, other than some of the bleeding periods, were the same for both groups. Sera were stored at $-20^{\circ} \mathrm{C}$. until required for testing.

Fluorescent antibody tests. These were carried out in Edinburgh as described by Gilmour (1971). The antigens were prepared from the same strains as were used to 
inoculate the rabbits. Suspensions of the antigens were standardised and films made on gelatin-coated slides. The antigen spots were exposed to the test sera for $30 \mathrm{~min}$. at room temperature and then to Difco* anti-rabbit or anti-cattle globulin fluorescein isothiocyanate conjugates. The tests were read with a Reichert "Zetopan" microscope using a HBO-200 mercury vapour lamp, a UGI $/ 1.5 \mathrm{~mm}$. exciter filter, dark ground condenser, GG $13 / 3+1 \mathrm{~mm}$. barrier filter, $\times 60$ glycerine-immersion objective and $\times 8$ eye piece. Sera were tested at doubling dilutions from $1 / 16$. The Dutch cattle sera and appropriate control sera were inactivated at $60^{\circ} \mathrm{C}$. for $30 \mathrm{~min}$. The cattle were tested in addition with $M$. avium antigen.

Complement fixation tests. Micro-complement fixation tests with $C$. renale and $M$. johnei antigens were carried out in Utrecht and the results classified into positive, weak positive, doubtful and negative as described by Goudswaard (1971b). The sera were inactivated at $58^{\circ} \mathrm{C}$. for $40 \mathrm{~min}$.

Cattle sera. The sera from the 17 clinical cases of Johne's disease were obtained from cattle killed at the Central Veterinary Laboratory, Weybridge, England. Those from the 10 cases of pyelonephritis in the Netherlands were from cattle with clinical symptoms from the urines of which $C$. renale was isolated in all cases. Autopsies were not done on all animals as some recovered as a result of penicillin therapy, while others were eventually slaughtered in other parts of the country: in consequence, no knowledge of the $M$. johnei infection status of all these animals could be determined.

\section{KESULTS}

Pre-inoculation sera from all the experimental rabbits were tested with the F.A. test only. There were no reactors to $C$. renale or $M$. johnei antigens. The results of F.A. and C.F. tests using both $C$. renale and $M$. johne $i$ antigens are given in Table 1. The $C$. renale inoculated rabbits were bled 3,4 and 7 months after inoculation. There was insufficient serum for the F.A. tests at 7 months since it had been used in previous experiments involving a less satisfactory antigen system. The $M$. johnei inoculated rabbits were bled at 4 months after inoculation. Two $C$. renale inoculated rabbits died during the experiment. No specific lesions were found in them or in any other rabbit in the experiment.

The results of C.F. and F.A. tests on sera from the 17 cattle with Johne's disease and from the 10 Dutch cases of pyelonephritis are summarised in Table 2. There were no F.A. reactions to $M$. avium antigen in either group of cattle.

\section{DISGUSSION}

Apparently non-specific G.F. test results were obtained from the sera of rabbits inoculated with either $C$. renale or $M$. johnei. This finding suggests that the antigens described by Cummins (1962) as being common to corynebacteria and mycobacteria, are detected by the C.F. test. On the other hand, the F.A. test with both antigens was specific. As it was impossible to ascertain that the cases of Johne's disease in cattle had had no experience of $C$. renale (infections with this organisms can occur in the absence of clinical disease as shown by Hiramune, Murase and Yanagawa (1970)), or that the cattle with pyelonephritis were free from $M$. johnei infection it is not possible to say whether the F.A. results were, in fact, non-specific, but it is relevant to note that no cattle in the pyelonephritis

\footnotetext{
- Difco Laboratories, PO Box 14B, East Molesey, Surrey.
} 


\section{TABLE 1}

RESULTS OF COMPLEMENT FDXATION (CF) AND FLUOREBGENT ANTIBODY (FA) TESTS

Sera from rabbits inoculated with $C$. renale and $M$. johnei

\begin{tabular}{|c|c|c|c|c|c|c|c|c|c|c|c|c|c|}
\hline \multirow[b]{3}{*}{ 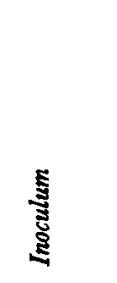 } & \multirow[b]{3}{*}{ : } & \multirow{3}{*}{ 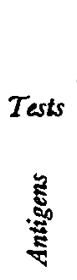 } & \multicolumn{4}{|c|}{3} & \multicolumn{4}{|c|}{$\begin{array}{l}\text { Months after inoculation } \\
\qquad 4\end{array}$} & \multirow{2}{*}{\multicolumn{3}{|c|}{$\frac{7}{C F}$}} \\
\hline & & & \multicolumn{2}{|c|}{$C F$} & \multicolumn{2}{|c|}{$F A$} & \multicolumn{2}{|c|}{$C F$} & \multicolumn{2}{|c|}{$F A$} & & & \\
\hline & & & 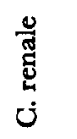 & $\begin{array}{l}\overrightarrow{\mathrm{d}} \\
\stackrel{5}{\circ} \\
\stackrel{\mathrm{s}}{\mathbf{\Sigma}}\end{array}$ & ن & 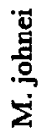 & ن & 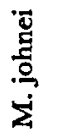 & 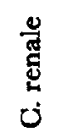 & & 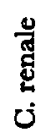 & & $\begin{array}{l}\overline{\mathrm{g}} \\
\stackrel{\mathrm{g}}{\mathrm{g}} \\
\stackrel{\mathrm{\Sigma}}{\mathrm{\Sigma}}\end{array}$ \\
\hline C. renale & $\begin{array}{l}5 \\
6 \\
7 \\
8\end{array}$ & & $\begin{array}{l}\stackrel{+}{W} P \\
\dot{\dagger} \\
\dot{W} P\end{array}$ & $\begin{array}{l}\stackrel{+}{W P} \\
w P\end{array}$ & $\begin{array}{c}128 * \\
64 \\
64 \\
64\end{array}$ & $\begin{array}{l}\bar{z} \\
\bar{z}\end{array}$ & $\begin{array}{l}\stackrel{+}{W P} \\
+ \\
-\end{array}$ & $\frac{\stackrel{+}{W P}}{\bar{D}}$ & $\begin{array}{r}128 \\
128 \\
64 \\
32\end{array}$ & $\begin{array}{l}- \\
\overline{-}\end{array}$ & $\begin{array}{l}+ \\
\mathrm{D}\end{array}$ & $\begin{array}{l}\text { dead } \\
\text { dead }\end{array}$ & $\begin{array}{l}\text { WP } \\
\text { WP }\end{array}$ \\
\hline M. johnei & $\begin{array}{l}1 \\
2 \\
3 \\
4\end{array}$ & & & & & & $\begin{array}{l}\text { D } \\
\text { D } \\
\text { D } \\
\text { WP }\end{array}$ & $\begin{array}{l}+ \\
+ \\
+ \\
+\end{array}$ & $\begin{array}{l}- \\
\overline{-}\end{array}$ & $\begin{array}{r}256 \\
128 \\
64 \\
64\end{array}$ & & & \\
\hline
\end{tabular}

No result $=$ test not done

- $=\frac{1}{\text { titre }}$

$-=\mathrm{CF}$ test negative or FA titre $<1 / 16$ $+\frac{1}{1}=$ CF test positive

WP $=$ CF test weak positive

$\mathrm{D}=\mathrm{CF}$ test doubtful

$\dagger=$ The 3 months serum from rabbit 7 was lost in transit

TABLE 2

CATTLE WITH JOHNE'S DISEASE AND PYELONEPHRTTS

Reactors to the C.F. and F.A. tests for C. renale and for Johne's disease

\begin{tabular}{|c|c|c|c|c|c|}
\hline \multirow{5}{*}{$\begin{array}{l}\text { Cattle affected with } \\
\text { Johne's disease } \\
\text { (17 cases, Weybridge) }\end{array}$} & \multirow{3}{*}{$\begin{array}{r}\text { Test } \\
\text { Negative }\end{array}$} & \multicolumn{4}{|c|}{ Antigen } \\
\hline & & \multicolumn{2}{|c|}{ C. renale } & \multicolumn{2}{|c|}{ M. johnei } \\
\hline & & $\begin{array}{l}C F \\
14\end{array}$ & $\begin{array}{l}F A \\
14\end{array}$ & $\begin{array}{r}C F \\
2\end{array}$ & $F A$ \\
\hline & Doubtful & & & & \\
\hline & $\begin{array}{l}\text { Weakly positive } \\
\text { Positive }\end{array}$ & $\begin{array}{l}2 \\
1\end{array}$ & 3* & $\frac{2}{13}$ & 17 \\
\hline \multirow{4}{*}{$\begin{array}{l}\text { Pyelonephritis due to } C \text {. renale } \\
\text { (10 cases, Netherlands) }\end{array}$} & Negative & & 1 & & 8 \\
\hline & Doubtful & & & 3 & \\
\hline & $\begin{array}{l}\text { Weakly positive } \\
\text { Positive }\end{array}$ & 3 & 0 & 4 & \\
\hline & rositive & & & & $2 T$ \\
\hline
\end{tabular}

Note: F.A. titres of $1 / 16$, the lowest dilution tested, are considered as positive.

* In these animals the titres to $M$. johnei were 2-, 8-, and 8-fold higher than to $C$. renale.

$\dagger$ In these animals the titres to $C$. renale were 2-, and 16-fold higher than to $M$. johnei.

group reacted to $M$. avium antigen. Exposure to this antigen at least was probably not a cause of the C.F. reactions to $M$. johnei. However, apparently non-specific C.F. results occurred at a much greater level in both rabbits and cattle. It is likely, therefore, that at least some of the C.F. results in cattle were due to antigen cross-reactivity and that $C$. renale infection could be an explanation for some of the apparently non-specific reactions to the C.F. test for Johne's disease which have been found in cattle. 
Complement fixation (C.F.) tests and fluorescent antibody (F.A.) tests were carried out on sera from rabbits inoculated with Corynebacterium renale and Mycobacterium johnei, and on sera from cattle with C. renale pyelonephritis and with Johne's disease. Cross-reactions were a feature of the C.F. test with both antigens on sera from rabbits and cattle with both infections. Positive C.F. tests for Johne's disease could, therefore, result from $C$. renale infection. The F.A. test was highly specific in the artificially infected rabbits and more specific than the C.F. test in cattle with the natural diseases.

\section{ACKNOWLEDGMENTS}

The authors are pleased to acknowledge the technical assistance of Mr. William Ramsay and wish to thank Mr. Maurice Allen, B.V.Sc., M.R.C.V.S., Biochemistry Department, Central Veterinary Laboratory, Weybridge, for the sera from cases of Johne's disease and practitioners in the Netherlands for collecting the serum and urine samples from the cattle with pyelonephritis.

\section{REFERENGES}

Breed, R. S., Murray, E. G. D., and Smith, N. R. (1957). Bergey's Manual of Determinative Bacteriology, 7th ed., Baillière, Tindall \& Cox; London.

Cummins, C. S. (1962). J. gen. Microbiol., 28, 35.

Gilmour, N. J. L. (1971). Res. vet. Sci., 12, 295.

Goudswaard, J. (1971a). Tijdschr. Dierg., 96, 528; (1971b). Dissertation, Utrecht.

Hiramune, T., Murase, N., and Yanagawa, R. (1970). Jap. J. vet. Sci., 32, 235.

Rankin, J. D. (1961). Res. vet. Sci., 2, 89.

Reinders, J. S. (1963). Dissertation, Utrecht.

[Received for publication, October 4th, 1971] 